\title{
MELALUI STIMULASI MINAT BACA DAPAT MENINGKATKAN KOMPETENSI DAN KINERJA GURU DALAM MENGAJAR DI MADRASAH TSANAWIYAH NEGERI 1 LANGKAT
}

\author{
Ojar \\ Surel: ojarsagmm@gmail.com
}

\begin{abstract}
The results of the school action research conducted by the author indicate that the value acquisition has increased very well, where the results of this study use quantitative data analysis with 10 respondents as the sample, while data management uses the product moment formula and t test. This can be seen from the correlation of the results of the calculation of the first cycle to the second cycle of Teacher Competence of 0.838 (categorized as very valid) with a t test value of 7.942 (categorized as very significant). And the correlation of the calculation results of the first cycle to the second cycle of Teacher Performance is 0.859 (categorized as very valid) with a t-test value of 9.315 (categorized as very significant). While all arithmetic results are greater than the table results, $r$ table is 0.317 and t table is 0.727 .
\end{abstract}

Keywords: Reading Interest Stimulation, Competence, Teacher Performance

\begin{abstract}
ABSTRAK
Hasil penelitian tindakan sekolah yang dilakukan oleh penulis menunjukkan bahwa perolehan nilai terjadi peningkatan yang sangat baik, dimana hasil penelitian ini menggunakan jenis analisis data secara kuantitatif dengan 10 responden sebagai sampel, sementara pengelolaan data memakai rumus product moment dan uji t. Hal ini dapat dilihat dari korelasi hasil perhitungan siklus pertama terhadap siklus kedua tentang Kompetensi Guru sebesar 0,838 (dikategorikan sangat valid) dengan nilai Uji t sebesar 7,942 (dikategorikan sangat signifikan). Dan korelasi hasil perhitungan siklus pertama terhadap siklus kedua tentang Kinerja Guru sebesar 0,859 (dikategorikan sangat valid) dengan nilai Uji t sebesar 9,315 (dikategorikan sangat signifikan). Sementara semua hasil hitung lebih besar dari hasil tabel, $r$ tabel sebesar 0,317 dan $t$ tabel sebesar 0,727 .
\end{abstract}

Kata Kunci: Stimulasi Minat Baca, Kompetensi, Kinerja Guru

\section{PENDAHULUAN}

Salah satu aspek penentu upaya peningkatan standar mutu bagi guru adalah wawasan intelektual guru menopang kompetensi mengajar. Ini merupakan syarat guru dalam melaku kan inovasi diri guna meningkatkan kinerja sebagai seorang pendidik dan pengajar di kelas. Dalam hal ini penulis selaku peneliti sekaligus Pengawas Sekolah memberikan apresiasi terhadap kemajuan sekolah terutama aspek kemampuan pengetahuan guru dalam melakukan kegiatan belajar mengajar di kelas.

Tujuan Pendidikan Nasional Indonesia tertuang dalam Garis-Garis besar Haluan Negara 2004 adalah untuk meningkatkan ketaqwaan terhadap Tuhan Yang Maha Esa, kecerdasan, keterampilan, mengerti budi pekerti, memperkuat 
kepribadian dan mempertebal semangat kebangsaan agar dapat menumbuhkan manusia bersamasama, bertanggung jawab atas pembangunan bangsa, (Lapasila IKIP Malang, 2004 :56). Hal tersebut diperjelas dalam Undang-Undang Republik Indonesia Sistem Pendidikan Nasional No. 20 Tahun 2003 pasal 39 ayat 2: Pendidikan Nasional mencerdaskan kehidupan bangsa dan mengembangkan manusia Indonesia seutuhnya yaitu manusia yang beriman dan bertaqwa kepada Tuhan Yang Maha Esa dan berbudi luhur memiliki pengetahuan dan rasa keterampilan, kesehatan jasmani dan rohani, rasa tanggung jawab kemasyarakatan dan kebangsa an. (Sisdiknas, 2003 :56). Sesuai dengan tujuan pendidikan tersebut, khususnya dalam usaha menyiapkan guru dalam meningkatkan kompetensi dan etos kerja mengajar di kelas maka diperlukan motivasi dan binaan secara positif dan simultan serta berkelanjutan dari Kepala Sekolah, hal ini diharapkan para guru memiliki kemandirian serta kemampuan akademik untuk mengajar serta mendidik para anak didiknya di lembaga pendidikan tingkat menengah yakni sekolah menengah.

Salah satu faktor pendukung guna meningkatkan motivasi mengajar, guru wajib membekali dirinya ilmu kependidikan dan usaha-usaha yang memacu peningkatan intelektual akademik dalam keselarasan mengajar terutama upaya meninggalkan gairah atau minat membaca pengetahuan kependidikan di luar rencana pelaksanaan pembelajaran di kelas secara kesadaran dan kemandirian guru tersebut. Menurut R. Widodo al, (1999:308) dijelaskan bahwa: Minat membaca, gemar membaca dan kebiasaan membaca yang baik merupakan dasar untuk mencapai keberhasilan dalam proses belajar mengajar. Dengan banyak membaca guru akan dapat memahami, mencerna, serta dapat mengamalkan ilmunya di kelas serta memiliki kapabilitas berbagai ilmu pengetahuan, kaya pengalaman dan wawasan.

Lebih lanjut dijelaskan Sowarno (1982:5) menambahkan bahwa: Membaca buku-buku referensial kependidikan dan berkreativitas untuk menulis ataupun mengarang merupakan kegiatan yang penting dalam kehidupan guru. Dengan membaca seorang guru dapat mengenal dan memahami beragam kenyataan nilai yang diungkapkan dalam materi buku dan bahasa serta dapat memadukan pengalaman pribadi dalam usaha menghadapi masa kini dan masa mendatang.

Perpustakaan yang tersedia harus lah diusahakan untuk melengkapi koleksi-koleksi bukunya dan diusaha kan untuk menyediakan buku-buku yang dapat menarik minat siswa untuk membacanya. Dengan cara demikian maka sedikit demi sedikit dapat menumbuhkan minat baca, gemar baca dan kebiasaan membaca. Di dalam lingkungan pendidikan untuk keperluan studinya orang lebih banyak membaca dari pada menulis. 
Untuk guru-guru di level lembaga formal pendidikan menengah, membaca refrensi kependidikan menjadi masalah yang penting karena guru akan dihadapkan oleh variasi problematika dalam kegiatan belajar mengajar di kelas. Dengan demikian keberadaan perpustakaan sangat membantu, karena kegiatan belajar mengajar dapat lebih efektif dan dapat menambah materi pelajaran dengan cara banyak membaca sumbersumber buku non paket di perpustakaan.

Selain itu, guru Madrasah Tsanawiyah Negeri 1 Langkat sedikit kesulitan dalam menyusun rencana pembelajaran, diantaranya : kurangnya gairah dan motivasi guru dalam pembinaan program kegiatan gemar membaca buku-buku referensi kepen didikan, kurangnya perhatian kinerja guru selama ini dalam aktivitas belajar mengajar di kelas, dan kurangnya upaya peningkatan kinerja guru dalam mengajar setelah para guru dalam pembinaan program kegiatan gemar membaca buku-buku referensi pendidikan.

Mengingat pentingnya peranan buku bacaan, maka sudah selayaknya minat membaca buku kajian-kajian kependidikan berupa artikel kependidikan, majalah kependidikan, serta buku-buku penunjang pembelajaran di kelas sudah harus ditanamkan pada diri guru sedini mungkin. Di sisi lain perpustakaan harus pula berbenah diri untuk lebih meningkatkan pelayanan dengan mengupayakan kelengkapan bukubuku dari berbagai bidang ilmu.
Selain itu, kepala Madrasah sebagai Pimpinan tertinggi hendaknya memperhatikan para guru diberbagai sisi, karena maju mundur nya suatu lembaga pendidikan tergantung kepada kemajuan kinerja guru sebagai tenaga pendidik.

Guru merupakan tokoh yang paling penting dalam pendidikan, hal ini dikarenakan guru berhubungan langsung dengan konsumen utama pendidikan yaitu peserta didik. Guru yang baik akan menjalankan kinerja nya secara professional walaupun benar dan resikonya cukup berat, termasuk guru SMP/MTs. "Kinerja guru" adalah seperangkat perilaku nyata yang ditunjukkan guru pada waktu dia memberikan pelajaran kepada siswanya. Kinerja guru dapat dilihat saat melaksanakan interaksi belajar mengajar di kelas termasuk bagaimana guru itu mempersiapkan rencana proses pembelajaran secara baik.

Penelitian ini memiliki tujuan sebagai berikut : untuk mengetahui melalui stimulasi minat baca dapat meningkatkan kompetensi guru dalam mengajar di Madrasah Tsanawiyah Negeri 1 Langkat, untuk mengetahui melalui stimulasi minat baca dapat meningkatkan kinerja guru dalam mengajar di Madrasah Tsanawiyah Negeri 1 Langkat.

\section{METODE PENELITIAN}

Prosedur ini melibatkan guruguru di Madrasah Tsanawiyah Negeri 1 Langkat Semester Genap yang berjumlah 10 orang. Penelitian ini 
dilakukan dua siklus dengan rincian sebagai berikut.

\section{Siklus I}

Perencanaan beberapa kegiatan yang dilakukan berikut ini : mengumpulkan guru-guru melalui undangan Kepala Sekolah, menyusun jadwal kegiatan penelitian tindakan hari, tanggal, jam dan tempat, menyiapkan materi kegiatan penelitian (pengarahan koordinator Pengawas dan Kepala Sekolah, pengarahan peneliti, pemaparan materi pengelolaan aktivitas gemar membaca buku-buku referensi kependidikan di perpustakaan), menyuruh guru membawa bahanbahan seperti kurikulum, silabus, RPP, bahan ajar dan sebagainya. Pemaparan kompetensi pengelolaan wajib membaca buku-buku referensi kepen didikan di perpustakaan sekolah sebagai berikut : Memberikan contoh membaca model-model pembelajaran inovatif yang bisa digunakan dalam metode mengajar yang lebih edukatif, Latihan penyusunan rencana pembelajaran sesuai dengan referensi bacaan dengan model pembelajaran yang lebih inovatif, Control dan penyusunan rencana pembelajaran sesuai dengan hasil resume bacaan referensi model pembelajaran yang inovatif. Menyusun laporan hasil Penelitian Tindakan Sekolah (PTS).

Observasi (Pengamatan):

Kesiapan mental dan fisik guru, Kesiapan bahan-bahan yang dibawa guru pada saat KBM, Kehadiran Guru, Hasil Sementara (Proses pelaksanaan kegiatan mengajar, Kualitas guru dalam mengajar, Respon guru terhadap hasil membaca referensi kependidikan.

$$
\text { Refleksi }
$$

(Cerminan): Indikator pencapaian, Pemanfaatan waktu terkait dengan rencana pembelajaran, Alokasi waktu untuk penyusunan rencana pembelajaran sesuai dengan indikator yang ditentukan dalam kom petensi, Materi kompetensi pada pengelolaan pembelajaran guru yang berhasil dalam penyusunan rencana pembelajaran sesuai dengan indikator keberhasilan setelah di observasi dianggap berhasil dan yang tidak berhasil dilan jutkan dalam siklus kedua dengan memperlihatkan kelemahan-kelemahan pada proses siklus pertama.

\section{Siklus II}

Perencanaan, beberapa kegiatan yang dilakukan sebagai berikut : hasil refleksi siklus pertama, menyiapkan materi penelitian tindakan, menyuruh guru membawa bahan-bahan seperti majalah kependidikan, artikel pembelajaran, termasuk RPP, bahan ajar dan sebagainya. Pemaparan kompetensi pengelolaan pembelajaran tentang model pembelajaran yang inovatif, Memberikan contoh model pembelajaran yang up to date bagi para guru yang belum memahami dari beberapa buku bacaan referensi pendidikan, Latihan penyusunan rencana pembelajaran, Control dan penyusunan rencana pembelajaran, Menyusun laporan hasil PTS. 
Observasi (Pengamatan): Kesiapan mental dan fisik guru, Kesiapan bahan-bahan yang dibawa guru pada saat Kegiatan Program Penyusunan RPP, Kehadiran Guru.

$$
\text { Refleksi }
$$

(Cerminan):

Indikator pencapaian, Pemanfaatan waktu terkait dengan rencana pembelajaran, Alokasi waktu untuk penyusunan rencana pembelajaran sesuai dengan indikator yang ditentukan dalam kompetensi, Materi kompetensi pada pengelolaan pembelajaran guru yang berhasil dalam penyusunan rencana pembelajaran sesuai dengan indikator keberhasilan setelah di observasi dianggap berhasil dan yang tidak berhasil dilanjutkan dalam siklus ketiga dengan memperlihatkan kelemahan-kelemahan pada proses siklus kedua. Apabila hasil refleksi pada siklus kedua sudah menunjukkan adanya peningkatan pada komponen dan kinerja guru secara signifikan, maka kegiatan penelitian dianggap berhasil, tetapi sebaliknya apabila belum menunjukan hasil yang di harapkan, maka kegiatan penelitian akan dilanjutkan dengan siklus berikutnya dengan langkah-langkah kegiatan yang sama dengan kegiatan pada siklus kedua ini.

Metode pengumpulan data, Teknik pengumpulan data dilakukan dengan cara pengisian lembar obeser vasi selama proses tindakan penelitian oleh Kepala Sekolah/Madrasah sehingga akan diperoleh data kualitatif sebagai hasil penelitian. Instrumen penelitian yang digunakan adalah lembar observasi yang digunakan oleh peneliti untuk mencatat perkembangan kemampuan masing-masing guru yang dibinanya selama proses penelitian (siklus 1 dan siklus 2).

Metode analisis data, Teknik analsis data dilakukan terhadap hasil RPP guru sebagai data awal kemampuan guru dan hasil observasi yang dilakukan selama proses pembinaan akan analisis secara deskriptif (kuantitatif) untuk mengukur keberhasilan proses pembinaan sesuai dengan tuju an penelitian tindakan sekolah ini. Dalam teknik analisis data ini diperlukan rumus untuk penguji instrumen. Untuk melihat instrument itu sahih, maka hasil instrument penelitian dihitung dengan menggunakan rumus validitas tes, reliabilitas tes, tingkat kesukaran tes, dan daya pembeda tes.

\section{HASIL PENELITIAN DAN PEMBAHASAN}

Penelitian tindakan sekolah (PIS) ini diusahakan mampu mena- warkan pendekatan dan prosedur baru yang lebih menjanjikan dampak langsung dalam bentuk perbaikan dan peningkatan profesionalisme guru dalam mengelola kegiatan be- lajar mengajar atau implementasi barbagai program di sekolah dengan mengkaji berbagai indikator keberhasilan proses dan hasil pembelajaran yang terjadi di sekolah. Penelitian tindakan ini merupakan studi yang sistematis yang dilakukan dalam upaya memperbaiki praktek-praktek dalam 
pendidikan dengan melakukan tindakan-tindakan praktis serta refleksi dari suatu rangkaian siklus yang berkelanjutan dan diantara siklus-siklus itu ada informasi yang merupakan balikan. Bentuk penelitian tindakan ini bersifat kola- boratif dan partisipatoris, artinya kolaboratif diterapkan untuk menciptakan adanya hubungan kesejawatan kerja, sedangkan partisipatoris merupakan penelitian tindakan yang pada pelaksanaannya melibatkan guru kelas.

Penelitian tindakan sekolah ini dilaksanakan di Madrasah Tsanawiyah Negeri 1 Langkat yang ber- alamat di jalan Pembangunan no.3 desa Pekubuan kecamatan Tanjung Pura kabupaten Langkat Sumatera Utara, dan 10 orang guru sebagai sampel.

\section{Pembahasan}

Instrumen Penelitian yang digunakan dalam penelitian ini di kembangkan instrumen pedoman observasi dalam program penyusunan RPP dari awal sampai akhir pada setiap siklus. Pedoman Observasi digunakan untuk menggali respon pada guru sedangkan pedoman wawancara digunakan untuk melengkapi data yang digali melalui pedoman observasi. Hasil observasi kompetensi guru tentang model pembinaan program gemar membaca buku-buku referensi kependidikan pada siklus I dilaksanakan sebanyak 2 kali dapat dilihat pada tabel berikut:
Tabel 1. Analisis Hasil Observasi Kompetensi Guru tentang Pembinaan Program Kegiatan Gemar Membaca pada 10 Orang Guru Siklus Pertama di Madrasah Tsanawiyah Negeri 1 Langkat

\begin{tabular}{|c|c|c|c|c|c|c|c|c|c|}
\hline \multirow[b]{2}{*}{ so } & \multirow[b]{2}{*}{ Itruitas } & \multicolumn{5}{|c|}{ Intrumant } & \multirow[b]{2}{*}{ Dantah } & \multirow[b]{2}{*}{5 corre } & \multirow[b]{2}{*}{$x . x$} \\
\hline & & 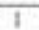 & 2 & 3 & 4 & 5 & & & \\
\hline 1 & Garu petams & 2 & 2 & 2 & 2 & 2 & 10 & 50 & 2500 \\
\hline 2 & Corr kodia & 3 & 3 & 3 & 3 & 2 & 14 & 70 & 4900 \\
\hline 3. & Grovkrtiga & 3 & 2 & 2 & 2 & 2 & 11 & 55 & 3025 \\
\hline 4 & Gasu ketrpai & 3 & 3 & 3 & 3 & 2 & 14 & 69 & 4225 \\
\hline 5 & Oaru ketina & 3 & 3 & 3 & 3 & 2 & 14 & 67 & 4489 \\
\hline 6 & Gun ketiali & 3 & 3 & 3 & 3 & 3 & 15 & 75 & 3625 \\
\hline 7 & Caru ketugh & 3 & 3 & 2 & 2 & 2 & 12 & 60 & 3600 \\
\hline 8 & Crubedelapan & 3 & 3 & 3 & 2 & 2 & 13 & 65 & 4225 \\
\hline 9 & Garu kesonbîn & 3 & 3 & 2 & 2 & 2 & 12 & 60 & 3600 \\
\hline 10 & Grot kexgukh & 3 & 3 & 3 & 3 & 2 & 14 & 70 & 4900 \\
\hline & Rata - Rata & 29 & 28 & 26 & 25 & 21 & 129 & 63,7 & \\
\hline
\end{tabular}

Diperoleh rata-rata hasil observa si kompetensi guru pada siklus pertama sebesar 63,7. Hasil observasi kinerja guru tentang model pembinaan program gemar membaca bukubuku referensi kepen didikan pada siklus I dilaksanakan sebanyak 2 kali dapat dilihat pada tabel berikut:

Tabel 2. Analisis Hasil Observasi Kinerja Guru tentang Pembinaan Program Kegiatan Gemar Membaca pada 10 Orang Guru Siklus Pertama di Madrasah Tsanawiyah Negeri 1 Langkat

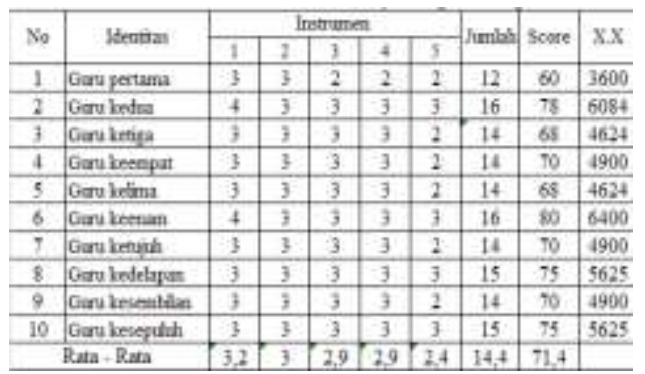

Diperoleh rata-rata hasil observa si kinerja guru pada siklus pertama sebesar 71,4. Hasil observasi kompetensi guru tentang model pembinaan program gemar membaca buku-buku referensi kependidikan pada siklus II dilaksanakan sebanyak 2 kali dapat dilihat pada tabel berikut: 
Ojar : Melalui Stimulasi Minat Baca Dapat ...

Tabel 3. Analisis Hasil Observasi Kompetensi Guru tentang Pembinaan Program Kegiatan Gemar Membaca pada 10 Orang Guru Siklus Pertama di Madrasah Tsanawiyah Negeri 1 Langkat

\begin{tabular}{|c|c|c|c|c|c|c|c|c|c|}
\hline \multirow{2}{*}{ No } & \multirow{2}{*}{ 1Aentis: } & \multicolumn{5}{|c|}{ Intrumen } & \multirow{2}{*}{ Jimbis: } & \multirow{2}{*}{ Scere } & \multirow{2}{*}{$\mathrm{X} . \mathrm{X}$} \\
\hline & & 1 & 2 & 3 & 4 & 3 & & & \\
\hline 1 & Garu pertuma: & 3 & 3 & 3 & 3 & 2 & 14 & 70 & 4900 \\
\hline 2 & Garukede & 4 & 4 & 3 & 3 & 3 & 17 & 82 & 6724 \\
\hline 3 & Cans beriga & 3 & 3 & 3 & 3 & 3. & 15 & 35 & 3623 \\
\hline 4 & Gon knespat & 3 & 3 & 3 & 3 & 3 & 15 & 75 & 5625 \\
\hline 5 & Canu krima & 3 & 3 & 3 & 3 & 3 & 15 & 75 & 5625 \\
\hline 6 & Gan ketian & 4 & 4 & 3 & 3 & 3 & 17 & 53 & 6889 \\
\hline 7 & Geru ketugh & 3 & 3 & 3 & 3 & 3 & 15 & 75 & 5625 \\
\hline 8 & Garu kntelapas & 4 & 3 & 3 & 3 & 3 & 16 & 80 & 6400 \\
\hline 9 & Caru kespiabin & 4 & 3 & 3 & 3 & 3 & 16 & 73 & 6084 \\
\hline 10 & Oavinurdoh & 4 & 3 & 3 & 3 & 3. & 16 & $\pi$ & 5929 \\
\hline & Rata - Rata & 3,5 & 3.2 & 3 & 3 & 29 & 15.6 & $\pi$ & \\
\hline
\end{tabular}

Diperoleh rata-rata hasil observasi kompetensi guru pada siklus kedua sebesar 77. Hasil observasi kinerja guru tentang model pembinaan prog- ram gemar membaca buku-buku refe rensi kependidikan pada siklus kedua dilaksanakan sebanyak 2 kali dapat dilihat pada tabel berikut :

Tabel 4. Analisis Hasil Observasi Kinerja Guru tentang Pembinaan Program Kegiatan Gemar Membaca pada 10 Orang Guru Siklus Pertama di Madrasah Tsanawiyah Negeri 1 Langkat

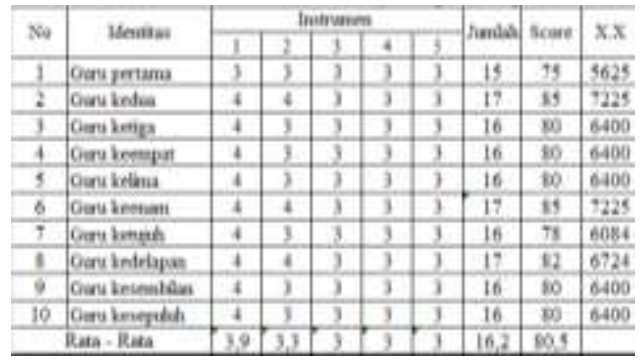

Diperoleh rata-rata hasil observa si kompetensi guru pada siklus kedua sebesar 80,5. Dilihat hasil perhitung- an rataan dari siklus pertama dan ke- dua di atas semakin meningkat.

\section{Pembahasan}

Berdasarkan hasil observasi kompetensi guru pada siklus I dan siklus II yang telah dilakukan pengelolaan data dengan hasil perhitungan tingkat rata-rata test, korelasi test (Product Moment), dan Uji t (validitas test), dapat dilihat pada tabel sebagai berikut :

Tabel 5. Rangkuman Validitas Kompetensi Guru tentang Pembinaan Program Kegiatan Gemar Membaca pada 10 Orang Guru Siklus Pertama di Madrasah Tsanawiyah Negeri 1 Langkat

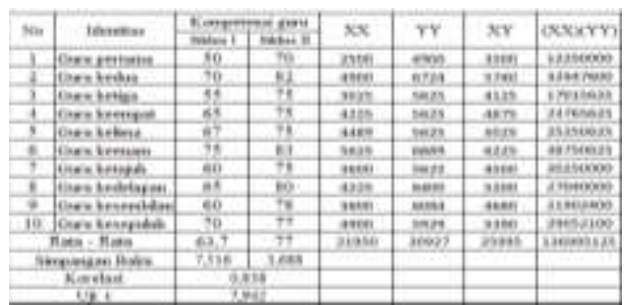

Dari tabel di atas nilai rata-rata sebesar 63,7 pada siklus pertama dan sebesar 77 pada siklus kedua, nilai simpangan baku sebesar 7,516 pada siklus pertama dan sebesar 3,688 pada siklus kedua, nilai korelasi sebesar 0,838 dan uji $t$ sebesar 7,942 semuanya dikatagorikan signifikan.

Berikut hasil observasi kinerja guru pada siklus I dan siklus II yang telah dilakukan pengelolaan data dengan hasil perhitungan dilihat pada tabel sebagai berikut:

Tabel 6. Rangkuman Validitas Kinerja Guru tentang Pembinaan Program Kegiatan Gemar Membaca pada 10 Orang Guru Siklus Pertama di Madrasah Tsanawiyah Negeri 1 Langkat

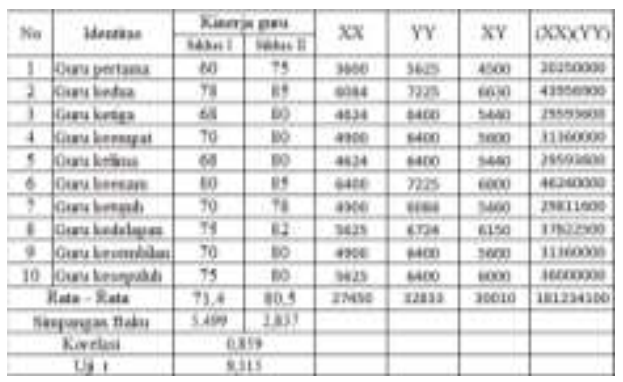


Dari tabel di atas nilai ratarata sebesar 71,4 pada siklus pertama dan sebesar 80,5 pada siklus kedua, nilai simpangan baku sebesar 5,499 pada siklus pertama dan sebesar 2,837 pada siklus kedua, nilai korelasi sebesar 0,859 dan uji t sebesar 9,315 semuanya dikatagorikan signifikan.

Berikut hasil observasi nilai rata-rata kompetensi dan kinerja guru pada siklus I dan siklus II yang telah dilakukan pengelolaan data pada diagram batang sebagai berikut :

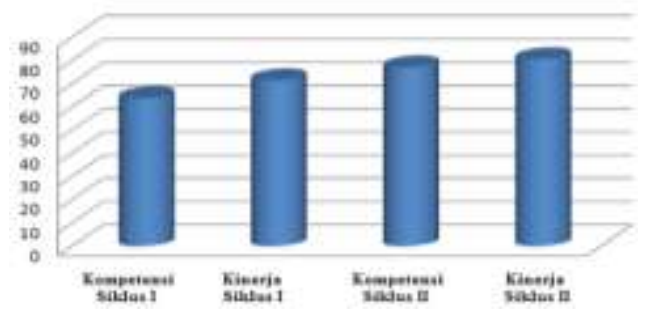

Gambar 1. Diagram Batang Nilai Rata-rata Kompetensi dan Kinerja 10 Orang Guru MTsN 1 Langkat

Dari diagram batang nilai ratarata kompetensi dan kinerja guru pada siklus I dan siklus II meningkat, ini dikatagorikan tinggi.

Berikut hasil observasi nilai simpangan baku kompetensi dan kinerja guru pada siklus I dan siklus II yang telah dilakukan pengelolaan data pada diagram batang sebagai berikut :

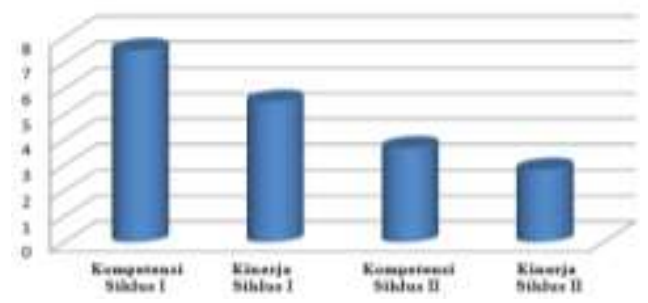

Gambar 2. Diagram Batang Nilai Simpangan Baku Kompetensi dan Kinerja 10 Orang Guru MTsN 1 Langkat
Dari diagram batang nilai simpangan baku kompetensi dan kinerja guru pada siklus I dan siklus II meningkat, ini dikatagorikan sangat signifikan. Artinya penelitian tindakan sekolah ini menunjukkan bahwa melalui stimulasi minat baca dapat meningkatkan kompetensi guru dalam mengajar di Madrasah Tsanawiyah Negeri 1 Langkat.

\section{SIMPULAN}

Adapun kesimpulan yang dapat diambil pada penelitian ini adalah :

- Melalui Stimulasi Minat Baca Referensi Kependidikan di Perpustakaan Sekolah dapat Meningkatkan Kompetensi Guru Dalam Mengajar di MTsN 1 Langkat Semester Genap Tahun Pelajaran 2018/2019, hal ini dapat dilihat dari hasil perhitungan siklus pertama terhadap siklus kedua dengan nilai validitas sebesar 0,838 (dikategorikan sangat valid) dan nilai Uji t sebesar 7,942 (dikategorikan sangat signifi kan).

- Melalui Stimulasi Minat Baca Referensi Kependidikan di Perpustakaan Sekolah dapat Meningkatkan Kinerja Guru Dalam Mengajar di MTsN 1 Langkat Semester Genap Tahun Pelajaran 2018/2019, hal ini dapat dilihat dari hasil perhitungan siklus pertama terhadap siklus kedua dengan nilai validitas sebesar 0,859 (dikategorikan sangat valid) dan nilai Uji t sebesar 9,315 
Ojar : Melalui Stimulasi Minat Baca Dapat ...

(yang dikategorikan sangat signifikan).

\section{DAFTAR RUJUKAN}

Anas, Sudiyono. 2003. Statistik. Jakarta : Granfindo Pustaka.

Arikunto, Suharsimi. 1993. Prosedur Penelitian. Jakarta: Rineka Cipta.

Bahar, Ahmad dan Sholeh, Zuhri. 2006. Penuntun Praktis Cara Belajar Mengajar Yang Efisien. Jakarta: Karya Utama.

Departemen Pendidikan Nasional. 2003. Dasar-Dasar Kependidikan. Jakarta: Dirjen Pendidikan Dasar dan Menengah

Hadari, Nawawi. 2005. Metodologi Penelitian Tindakan. Yogyakarta: Gadjah Mada University Press.

Hadi, Sutrisno. 1984. Metodologi Research. Yogyakarta: UGM Press.

Hadi, Sutrisno. 1988. Statistik 2. Yogyakarta: Andi Offset

Nasution dan Thomas. 2004. Azasazas Kurikulum SMP Tahun 2004. Jakarta: Depdiknas

Nana, Sudjana. 1986. Metode Statistik. Bandung: Tarsito

R., Widodo. 1989. Pedoman Pengelolaan Perpustakaan. Jakarta: Depdiknas 
